\title{
DA ORIGEM DA POESIA: SURGIMENTO E DECLÍNIO DAS LÍNGUAS EM Condillac
}

\author{
Fernão de Oliveira Salles ${ }^{1}$
}

Resumo: Trata-se de mostrar a importância das consideraçôes sobre a poesia, para a teoria de Condillac acerca da gênese e dos progressos da linguagem. Tais consideraçóes parecem, à primeira vista, apenas passos necessários para completar a história desse processo. Examinadas mais de perto, porém, elas adquirem um outro sentido e importância, pois, na medida em que indicam que o uso metafórico ou trópico dos signos é uma possibilidade dada desde o início da comunicação verbal, permitem pensar a respeito de suas vantagens e perigos. Esse último aspecto tem consequências graves para a concepção condillaciana do progresso da humanidade, as quais se pretende apenas indicar aqui.

Palavras-Chave: Poesia. Tropos. Signo. Linguagem de ação.

\section{INTRODUÇÃo}

Por que falar de poesia, na filosofia de Condillac? Ao contrário de diversos contemporâneos seus, esse autor não se destaca no emprego de recursos literários para dar forma a suas teses. Apesar da importância fundamental da linguagem para a filosofia condillaciana, seu estilo é, via de regra, cuidadosamente econômico e até mesmo árido. Condillac é extremamente parcimonioso no uso de metáforas, imagens e outras figuras de linguagem, buscando sempre eliminar ambiguidades e equivocidades e visando, sobretudo, à exatidão e à nitidez (netteté) em seu discurso. Mais que

1 Docente no Programa de Pós-Graduação em Filosofia da Universidade Federal de São Carlos (UFSCar), São Carlos, SP - Brasil. (ID https://orcid.org/0000-0003-2920-6590. E-mail: fernao. salles@gmail.com.

https://doi.org/10.1590/0101-3173.2021.v44n2.13.p181

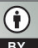


isso, a bem da verdade, suas consideraçôes sobre a arte poética parecem, à primeira vista, um tanto marginais a seus argumentos.

No Ensaio sobre a origem dos conhecimentos humanos (1746), por exemplo, o tema do surgimento dessa arte é abordado no curso de uma longa argumentação que pretende expor os progressos da linguagem e se orienta, primordialmente, para o desenvolvimento da fala e das diversas línguas. Anos mais tarde, em $A$ arte de escrever (1775), a poesia será tratada tendo a prosa como termo de comparação - além de ser, de modo geral, descrita como um uso da linguagem que visa mais ao agrado que ao conhecimento, principal preocupação do filósofo. Não que não haja mistura de ambas, ou que a poesia não possa em alguma medida instruir, mas, enquanto ela se faz principalmente com o intuito de agradar ao gosto, é a prosa que enseja a análise precisa dos objetos e das ideias, bem como de suas relaçóes. Filósofo e poeta buscam atingir objetivos distintos: a poesia, à semelhança da pintura, emprega imagens e apresenta suas ideias em "massas", misturadas, talvez possamos dizer, de maneira agradável à nossa sensibilidade, pouco se preocupando com o rigor analítico que caracteriza a filosofia.

Com efeito, essa disciplina objetiva a descoberta ou a demonstração da verdade, e o método que emprega para tanto é justamente a análise que deslinda e decompóe as ideias que aparecem misturadas em nossa experiência, bem como a determinação das relaçóes que se pode estabelecer entre elas. Por isso mesmo, a prosa se constitui como o uso da linguagem mais adequado à filosofia, e as exigências de seu estilo serão, em princípio, pensadas com vistas mais à exatidão e à clareza do que à beleza e à fruição. Em se tratando do texto filosófico, resta à poesia uma função meramente auxiliar, como deixa claro o texto de $A$ arte de escrever:

O filósofo analisa para descobrir uma verdade ou para demonstrá-la. Se por vezes emprega imagens é, não é tanto por querer pintar quanto por querer tornar mais sensível uma verdade, as imagens encontram-se sempre subordinadas ao raciocínio. Um escritor que queira pintar, e apenas pintar, escreve sobre verdades conhecidas, ou sobre opiniôes que se consideram verdadeiras. Como não precisa decompor suas ideias ele as apresenta em massas: sáo imagens em que seu assunto se encontra mesmo que pareçam dele se desviar. Se raciocina, é unicamente para dar mais variedade aos quadros que pinta, e seus raciocínios, subordinados sempre ao desenho, são precisos, rápidos, contidos às vezes numa expressão que em si mesma é uma imagem (CONDILLAC, 2018, p. 328). 
Se é assim, é natural que a poesia pareça, a princípio, merecer consideraçóes um tanto marginais no sistema de Condillac. Dada a conhecida preocupação do abade em relação à teoria do conhecimento e à metafísica, se a função da poesia em relação à filosofia se resume ao papel acessório de tornar a verdade sensível ao leitor, a arte poética parece, à primeira vista, relegada a segundo plano. A leitura que se pretende fazer aqui, no entanto, visa a mostrar que o capítulo do Ensaio sobre a origem dos conhecimentos humanos, onde o surgimento da poesia é reconstituído, náo apenas cumpre o papel de inserir a gênese desse modo de expressão no quadro de geral de uma história da linguagem e das artes, mas termina por tornar claros alguns traços dos próprios signos linguísticos, cuja importância para a teoria da linguagem condillaciana nos parece inegável.

Trata-se de evidenciar, em outras palavras, que as consideraçóes a respeito da poesia, sobretudo do uso dos signos que a caracteriza, ocupam um lugar estratégico na filosofia condillaciana, pois, como se verá, elas são reveladoras de algumas virtudes e perigos inscritos na própria natureza dos signos.

\section{Poesia e figuração}

Esse lugar é indicado, antes de mais, pelo próprio ponto no qual a investigação acerca da gênese da poesia se inscreve, na argumentação condillaciana. Com efeito, tal exame finaliza um bloco de argumentos que visa a explicar como diversas artes contidas num germe comum - a linguagem de açâo - se despregam dessa raiz, passando a constituir registros linguísticos próprios.

Essa linguagem originária, composta de gestos, contorçóes da face e sons inarticulados, é a semente da qual germinam a dança, a declamação, a pantomima, o canto, a música e, por fim, a poesia. Cada um desses, por assim dizer, sistemas de expressão ${ }^{2}$ irá desdobrar algum aspecto contido, mas inicialmente não explicitado, nesse germe inicial, segundo podemos ler no Ensaio:

\footnotetext{
2 Convém notar que Condillac concebe as artes enquanto sistemas linguísticos. Quer dizer, objetos táo diferentes quanto a dança, a pantomima e a poesia são considerados como linguagens, sempre derivadas daquela raiz comum que se encontra na linguagem de ação.
} 
[...] encontrei na linguagem de açáo o germe das línguas e de todas as artes que possam servir à expressão de nossos pensamentos; observei as circunstâncias propícias ao desenvolvimento de tais germes; e não somente mostrei como da linguagem nascem as artes, como segui os seus progressos (CONDILLAC, 2018, p. 281).

A poesia, como as outras artes, será vista, portanto, como o desenvolvimento de alguma possibilidade dada de modo confuso na linguagem dos gestos; possibilidade essa que, conforme a necessidade se apresentar, se distinguirá das restantes; se constituirá como prática e, por fim, estabelecerá suas próprias regras, tornando-se, numa palavra, uma arte autônoma. Tratase, pois, de explicar o que Condillac considera como sendo propriamente um processo de geração.

Termo oriundo da fisiologia, a palavra "geração" fornece a chave e o modelo pelo qual Condillac compreenderá tanto o surgimento e os progressos da linguagem quanto o nascimento e a evolução das faculdades do homem. Por isso, pode-se dizer que fazer a história da linguagem equivale, para o filósofo, a descrever a maneira como algo se plasma a partir de um gérmen, respondendo a determinadas necessidades e se nutrindo de certas condiçóes. Trata-se de um processo pelo qual algo se constitui, passando por diversas etapas, ligadas umas às outras, e desenvolvendo diferentes potencialidades, até chegar a uma determinada forma. Ressalta o Dicionário de sinônimos:

A palavra geração é mais relativa ao que se passa numa coisa que se forma, e marca o desenvolvimento que nela se faz por graus. A palavra produção é mais relativa à causa, e marca somente que uma coisa que não existia começa a existir; geraçáo se diz propriamente dos animais, mas a estendemos aos vegetais e a todos os corpos. Fala-se até da geração das ideias, quando se quer explicar a maneira como nascem umas das outras (CONDILLAC, 1951, p. 299).

Ora, o primeiro passo dessa, por assim dizer, história natural ${ }^{3}$ da poesia consiste em demonstrar como tal arte está ligada à linguagem de ação. Ao contrário do que se poderia pensar, quando o uso poético da linguagem

3 O uso da expressão "história natural" nos parece legítimo aqui, dado que o exame da poesia está inscrito no interior da reconstituição da gênese da linguagem e, com ela, das faculdades superiores da alma. E, em ambos os casos, o termo "gênese" tem, como se tentou sublinhar, sua raiz na constituiçáo do animal, Não nos parece, aliás, ser por acaso que, em seu já clássico comentário, André Charrak (2003, p. 21) se refira à empreitada do filósofo no Ensaio como uma "história natural da alma". 
se institui, as línguas ainda se encontram em estado precário, dispondo de vocabulário pobre e, exatamente por isso, necessitando do auxílio dos gestos e da entonação de voz para exprimir nossas ideias. Ou seja, dada a insuficiência do léxico, nesse momento, linguagem de ação e fala encontram-se ainda misturadas. Por isso mesmo, nessa etapa do desenvolvimento da linguagem, a prosódia se aproxima do canto e as palavras são empregadas de maneira a imitar os gestos, gritos e contorçóes faciais. Nesse momento, como observa o filósofo, a fala imita o procedimento próprio da linguagem de ação e torna-se uma espécie de pintura, por meio de sons articulados:

Se na origem das línguas a prosódia teria se aproximado do canto, o estilo, a fim de copiar as imagens sensíveis da linguagem de ação, adotaria toda sorte de figuras e metáforas, e seria a verdadeira pintura. $\mathrm{Na}$ linguagem de ação, para dar a ideia de um homem ferido, não haveria outro meio a não ser imitar seus gritos e contorçóes. Quando se quisesse comunicar essa ideia por via de sons articulados, recorrer-se-ia a todas as expressóes que pudessem apresentá-la em detalhe (CONDILLAC, 2018, p. 221).

É importante notar que os aspectos que, aos olhos de Condillac, constituem o núcleo característico da poesia já estão dados nessa situação inicial. Por um lado, a musicalidade própria a essa arte está presente numa prosódia que retém as variaçôes melódicas e rítmicas características dos gritos da linguagem de ação, presentes também na raiz do canto. Por outro, nesse momento inicial, o uso das palavras é imagético, remetendo-se ao aspecto visual dos gestos e contorçóes faciais daquela primeira forma linguística. Se a linguagem de ação era, desde o início, figurativa, se era pela imitação ou indicação seus objetos que ela comunicava, a fala recorrerá à copiosidade reiterativa de palavras e imagens verbais ou, talvez possamos dizer, às figuras de linguagem, para transmitir as ideias e emoçóes que se quer comunicar (COSKI, 2006, p. 162). Nos termos do autor:

$\mathrm{Na}$ linguagem de ação, para dar a ideia de um homem ferido, não haveria outro meio a náo ser imitar seus gritos e contorçóes. Quando se quisesse comunicar essa ideia por via de sons articulados, recorrer-se-ia a todas as expressóes que pudessem apresentá-la em detalhe. Uma palavra sozinha que nada pintasse seria muito fraca para suceder a linguagem de ação. Essa linguagem era táo bem proporcionada à grosseria dos espíritos, que sons articulados só poderiam suplementá-la na medida em que as expressóes se acumulassem umas sobre as outras (CONDILLAC, 2018, p. 221). 
Nesse momento, o uso poético da fala não se deve, porém, a uma ação deliberada ou a um desígnio dos homens. Ele é, em certa medida, contingente e inadvertido, dado que é a própria limitação das primeiras línguas que acarreta esse modus operandi. Ainda distantes da riqueza terminológica, da abstração e da estrutura complexa das línguas modernas, as línguas primitivas devem, de acordo com as hipóteses levantadas no Ensaio, ter recorrido a figuras de linguagem e metáforas, para dizer aos ouvidos o que era dito aos olhos, através dos gestos e contorçóes faciais. O uso poético, presente já nos primórdios da fala, é nessa medida decorrência do caráter rudimentar de nossa condição primitiva. É, sobretudo, a pobreza lexical das primeiras línguas, a escassez de termos próprios para designar estados da alma e objetos, que impelem os homens a recorrerem a figuraçáo característica da poesia, na tentativa de ampliar sua capacidade de expressão:

A pobreza das línguas não permitiria que se falasse de outro jeito. Como dificilmente forneceriam o termo próprio, só seria possível adivinhar um pensamento à força de repetirem as ideias mais parecidas com ele (CONDILLAC, 2018, p. 221).

Tal uso só se tornará arte, no entanto, conforme as línguas forem enriquecendo seu vocabulário e a linguagem de açâo for perdendo espaço. Noutras palavras, a diversificação dos termos linguísticos é condição para que o uso poético da língua deixe de ser decorrente de mera necessidade e se converta em arte autônoma. Num movimento apenas aparentemente paradoxal, o enriquecimento do léxico libertará progressivamente a língua da linguagem de ação, distanciando cada vez mais o signo verbal do gesto e da pintura, abrindo espaço para um emprego mais abstrato e menos figurativo das palavras, constituindo, assim, a possibilidade da prosa. ${ }^{4} \mathrm{O}$ paradoxo é apenas aparente, pois a poesia passará a ser empregada visando aos efeitos e às vantagens que lhe são próprios, e não a fim de contornar as limitaçôes da língua. Em vez de ser abandonada, a poesia passará, então, a ser cultivada com vistas à realização de certos fins.

Isto é, se, apesar do surgimento da prosa, a poesia se constitui como arte, ou seja, como prática realizada mediante regras próprias para sua execução, é porque, malgrado essa nova variação, ela mantém alguma

\footnotetext{
4 "Quando as línguas se tornassem mais abundantes, porém, a linguagem de ação seria aos poucos abolida, a voz variaria menos, o gosto por figuras e metáforas, por razōes que explicarei, diminuiria gradualmente, e o estilo se aproximaria daquele de nossa prosa." (CONDILLAC, 2018, p. 222).
} 
utilidade. Sempre supondo os homens ainda em estado primitivo, Condillac atribui a sobrevivência da poesia ao fato de que o discurso poético, por sua vivacidade, se fixa facilmente na memória. A poesia se presta, assim, ao registro daquilo que é importante para as sociedades nascentes. Odes, hinos e salmos devem, conforme conjectura o autor, ter servido para registrar os feitos dos grandes homens, as leis e os princípios religiosos etc., em sociedades ainda desprovidas da escrita (CONDILLAC, 2018). Por isso, a despeito da diferenciação entre prosa e poesia, esta última, longe de ser abandonada, será agora premeditadamente cultivada.

Cabe, contudo, esclarecer mais exatamente como a poesia se torna arte. ${ }^{5}$ Seguindo um esquema recorrente em sua argumentação, Condillac faz a constituição das regras arte derivarem de sua própria prática, e não o contrário:

Mas os autores continuariam a adotar a linguagem antiga, como a mais viva e mais apta a ser gravada na memória, único meio de transmissão à posteridade. Dar-se-iam diferentes formas a essa linguagem, imaginar-seiam regras para ampliar sua harmonia, criar-se-ia, para tanto, uma arte particular (CONDILLAC, 2018, p. 222).

Como no caso de outras tantas artes e mesmo das ciências, as regras são descobertas à medida que os homens experimentam, como que por tateios, e vão constatando quais seriam as práticas mais bem-sucedidas. No caso da poesia, é enquanto empregam os recursos poéticos na produção de seus discursos que eles observam as combinaçôes silábicas mais agradáveis, ajustam os ritmos, as inflexóes de voz e estabelecem modelos de número, harmonia e versificação. É nesse processo que a poesia se distingue definitivamente dos outros usos da linguagem.

Se já se instituíra a diferenciação entre poesia e prosa, é à medida que a prática poética se aperfeiçoa, tornando-se cada vez mais consciente de suas próprias regras, que ocorre, por exemplo, a diferenciação entre poesia e música. "A música e a poesia, até então inseparáveis, se dividiriam gradualmente, à medida que se aperfeiçoassem, em duas artes diferentes (CONDILLAC, 2018, p. 225).” A invenção da escrita coroa esse movimento de diferenciação. Com efeito, a escritura substituirá a poesia, na função de prestar socorro à memória,

5 O termo "arte", conforme o Dicionário de sinônimos, designa o seguinte: "A palavra 'arte’ é entấo de uma grande extensão: é o nome que se dá a todo sistema de regras próprias para dirigir a prática. [...] Um sistema de leis que não se reporta à prática, ou que é considerado ao fazer a abstração da prática, é o que se nomeia 'ciência'. Pode-se ser artista sem possuir 'ciência' da 'arte'. Pode-se ser conhecedor da 'arte' sem ser 'artista'." (CONDILLAC, 2016, p. 272) . 
liberando a atividade do poeta para outros fins. A partir desse momento, o exercício dessa arte será orientado principalmente às "coisas do puro agrado", e a poesia finalmente tomará máxima distância da fala comum e da "linguagem ordinária”, colocando a instrução dos homens em segundo plano.

O cultivo autônomo da poesia, entretanto, não se dá sem riscos: se, nesse ponto de seu desenvolvimento, as metáforas e outras figuras de linguagem podem ser empregadas para tornar a exposição dos avanços do conhecimento humano mais "radiante" e "sublime", seu uso desmedido pode, em contrapartida, sobrecarregar o discurso, a ponto de os adornos se tornarem mais importantes do que aquilo que supostamente deveriam destacar, tornar sensível e embelezar:

A época de sua decadência inicia-se quando parecem querer se apropriar das maiores belezas. Vemos as metáforas e as figuras se acumularem, saturando o estilo com ornamentos a tal ponto que o fundo parece se tornar acessório (CONDILLAC, 2018, p. 267).

\section{LINGUAGEM E PENSAMENTO}

Afirmar que a sobrecarga de adornos está associada à decadência de uma língua não é pouca coisa para Condillac. Em sua filosofia, pensamento e linguagem estão estreitamente ligados. Afinal, é somente com o uso do signo, segundo ele, que realizamos as operaçóes mais complexas do espírito e obtemos o que poderíamos chamar de conhecimento teórico. ${ }^{6}$ Sequencialmente dispostos e ligados em uma proposição, os signos linguísticos ordenam os objetos da experiência e instauram com clareza uma série de relaçóes que nossos sentidos divisam apenas obscuramente, permitindo-nos, desse modo, generalizaçôes, valoraçôes e abstrações que seríamos totalmente incapazes de realizar sem a linguagem. ${ }^{7}$

\footnotetext{
${ }^{6}$ Refiro-me a importante distinção entre conhecimento teórico e conhecimento prático, elaborada pelo autor no Tratado das sensaçôes: "Mas é preciso distinguir, como fiz mais acima, conhecimentos teóricos e conhecimentos práticos. Ora, é para os primeiros que temos necessidade de uma linguagem, porque consistem numa sequência de ideias distintas, e por conseguinte foi necessário usar signos para classificá-los com ordem e determiná-los. Os conhecimentos práticos, pelo contrário, são ideias confusas, que regram nossas açóes, sem que sejamos capazes de observar como nos fazem agir." (CONDILLAC, 1993, p. 211).

7 É interessante notar que os mesmos objetos admitem diferentes representaçôes, conforme vária a perspectiva da análise. Como indica a Lingua dos cálculos: "Diferentes expressôes representam a mesma coisa sob diferentes relaçōes, e as visóes do espírito, vale dizer, as relaçōes sob as quais consideramos uma coisa, determinam a escolha que devemos fazer." (CONDILLAC, 2016, p. 214).
} 
Em suma, os signos são fundamentais para o pensamento, pois é por meio dessas "alavancas" do espírito que nos tornamos aptos a decompor e ordenar a massa de dados que os sentidos nos apresentam, de modo simultâneo e confuso. ${ }^{9}$ Essa operação é, na concepção de Condillac, a responsável pela descoberta da verdade, conforme se pode ler na carta ao Conde Potocki, datada de 23 de janeiro de 1779: "Ela [a análise] faz encontrar as verdades ao mesmo tempo que as demonstra e forma o espírito para a arte de inventar." (CONDILLAC, 1948, p. 553). Empregada de modo exemplar nas matemáticas, ela deve ser estendida aos demais campos do conhecimento, para garantir-lhes sua cientificidade. ${ }^{10}$ conforme a formulação do Ensaio:

Em todas as ciências, a exemplo da aritmética, a verdade só se deixa descobrir por composição e decomposição. Se o raciocínio ordinário não é dotado dessa mesma justeza, é porque ainda não encontrou regras certas para compor e decompor as ideias sempre com exatidáo, o que por sua vez provém de não ter sabido como determiná-las (CONDILLAC, 2018, p. 286).

Estritamente analítica, essa concepção de conhecimento repousa sobre a tese de que conhecer é tornar nítido aquilo que a experiência nos oferece de forma confusa, isto é, separar o que os sentidos nos apresentam misturado, formando, desse modo, um sistema, como ressaltará o autor, na mesma carta ao Conde Potocki: "É nossa atividade que extrai de nossas sensaçôes tudo

8 Utilizamos aqui o termo "alavancas", glosando o texto da Lógica: "Ora, assim como a arte de mover grandes massas possui suas leis nas faculdades do corpo e nas alavancas das quais nossos braços aprenderam a se servir, a arte de pensar tem as suas nas faculdades da alma e nas alavancas das quais nosso espírito igualmente aprendeu a se servir." (CONDILLAC, 2016, p. 20).

9 Para que se tenha a dimensão da importância desse ponto, o qual não iremos desenvolver aqui, vale mencionar a observação de Alain-Marc Rieu sobre o papel desempenhado pela linguagem, no empirismo francês do século XVIII: "A ordem das ideias não pode ser reduzida à ordem das percepçôes de um sujeito psicológico. Esse é o problema que as filosofias copernicanas têm a resolver: a consciência está em ruptura com o que ensina a percepção e, entretanto, ela repousa sobre a observação e a experiência que, somente elas, permitem descobrir as leis da natureza. O signo designa essa colocação das percepções em ordem no tableau uniforme das ideias. Ele mostra, e pode ser que dissimule também, a ruptura entre as duas ordens; a qual é reduzida por Condillac à oposição entre o sucessivo e o simultâneo [...]” (RIEU, 1982, p. 30).

${ }^{10} \mathrm{O}$ lugar das matemáticas, em Condillac, não é simples de determinar. Se as matemáticas fornecem aqui um modelo, não é no mesmo sentido que se dá nos sistemas racionalistas. Essas ciências são, como mostrará a última obra de Condillac, a Língua dos cálculos, casos exemplares da boa análise e de línguas bem-feitas. Assim, devem ser examinadas para que, a partir delas, possamos compreender melhor a própria operaçấo da análise e a formaçấo de uma língua bem-feita. Trata-se, como indica Auroux, de compreender, a posteriori, a "gramática" dessas ciências e extrair daí uma compreensão mais fina da análise em geral (AUROUX, 1981, p. XVIII). 
aquilo que elas encerram.” (CONDILLAC, 1948, p. 553). Essa atividade é a própria análise, operação mental que envolve um duplo movimento de distinção, ou separação de seus objetos e de reconstituição da ordem e das relaçôes sob as quais eles se apresentam. Afirma Condillac, no Tratado dos sistemas:

\begin{abstract}
O método que emprego para fazer esses sistemas, eu chamo de análise. Podese ver que ele encerra duas operaçóes: decompor e compor. Pela primeira, separamos todas ideias que pertencem a um assunto e as examinamos até que tenhamos descoberto a ideia que deve ter sido o germe de todas as outras. Pela segunda, as dispomos conforme a ordem de sua geração. Mas quanto mais mal feita for a decomposiçáo, tanto mais distantes estaremos de apreender a verdadeira geração (CONDILLAC, 1947, p. 213, nota b).
\end{abstract}

Embora, em sua obra posterior, o autor vá esposar a opiniāo de que essas operações podem, em certa medida, ser realizadas pelos sentidos, sem o auxílio da linguagem, os signos linguísticos são, desde o Ensaio, as ferramentas indispensáveis para seu desenvolvimento pleno. Não por acaso, em suas últimas obras, Condillac vai defender a tese de que as línguas devem ser entendidas como diferentes métodos analíticos, segundo se pode ler em $A$ Lingua dos cálculos, obra póstuma do filósofo: "Toda língua é um método analítico, e todo método analítico é uma língua.” (CONDILLAC, 2016, p. 213). Desenvolvida em toda sua amplitude apenas na obra tardia, essa concepçáo da linguagem como método de análise, vale notar, já se insinua no Ensaio, onde a necessidade de analisar a experiência e a utilidade da linguagem para esse fim são exploradas de forma extensa e constituem elementos sem os quais o filósofo náo seria capaz de explicar o surgimento das faculdades superiores do espírito.

Esse aspecto, no entanto, não esgota a relação entre linguagem e pensamento, em Condillac. As sensaçôes, as quais constituem a referência última dos termos linguísticos, nos afetam de modo prazeroso ou doloroso, ligam-se a diferentes ideias e adquirem diferentes valores, que vão infletir sobre o sentido das palavras. Esse último, aliás, evocará significados acessórios que vão depender de contingências históricas peculiares às diferentes comunidades humanas. Ou seja, a língua não só é determinante para o desenvolvimento pleno do pensamento, mas, simultaneamente, reflete o que o filósofo chamará de "gênio das naçôes" e, simultaneamente, reflui sobre ele, contribuindo para sua formação. Os termos linguísticos não apenas servem à análise, mas, além disso, seus usos exprimem e condicionam o caráter dos povos, refletindo 
suas inclinaçôes e valoraçôes. Em síntese, a linguagem de cada povo expressa diversos aspectos e valores de suas culturas, conforme o termo, que designa esta ou aquela ideia principal, se faz acompanhar do que o Condillac chama de ideias acessórias.

Os signos são arbitrários, quando são empregados pela primeira vez. Talvez por isso alguns creiam que eles não teriam caráter próprio. Mas eu pergunto: não é natural que cada nação combine suas ideias segundo o gênio que lhe é próprio, e acrescente, a um estoque de ideias principais, ideias acessórias, que afetam os homens diferentemente? Essas combinaçóes, autorizadas por um longo uso, são propriamente o que constitui o gênio de uma língua. [...] Se ele fosse abandonado, falar-se-ia uma língua estranha e incompreensível. Cabe ao tempo realizar mudanças mais consideráveis, colocando o povo como um todo em circunstâncias tais que o levem a ver as coisas de um jeito diferente (CONDILLAC, 2018, p. 280).

Assim, por exemplo, a agricultura, como lembra o Ensaio, era positivamente considerada entre os antigos romanos e se fazia acompanhar de ideias de nobreza e dignidade. Entre os francos, contudo, a mesma atividade era vista como ocupação servil e indigna, ideias acessórias sempre evocadas pelos termos que a designam:

No latim, por exemplo, termos de agricultura implicam ideias de nobreza que estão ausentes de nossa língua. A razão disso é evidente. Quando os romanos lançaram os fundamentos de seu império, não conheciam mais do que as artes necessárias. Tinham por elas uma estima táo maior por ser essencial que cada membro da república se ocupasse delas: desde cedo, o povo acostumou-se a considerar a agricultura com os mesmos olhos do general que a cultivava. [...] A estima dos francos pela arte militar, à qual deviam um poderoso império, só poderia levá-los a desprezar artes que não eram obrigados a cultivar por si mesmos e que entregavam aos cuidados de escravos. Daí que as ideias acessórias ligadas por eles aos termos de agricultura fossem bem diferentes das encontradas no latim (CONDILLAC, 2018, p. 269).

Não parece exagero, por conseguinte, afirmar que diferentes línguas produzirão diferentes modos de pensar, ou seja, diferentes recortes analíticos da experiência, bem como valoraçôes distintas. Toda língua expressará a maneira própria de pensar de seus falantes e retroagirá sobre ela. Derivado inicialmente das condições do clima, do governo, da economia e da história, o gênio de um povo plasma e, reciprocamente, é plasmado pela língua falada por 
esse mesmo povo (LIFSCHITZ, 2012, p. 550). Talvez, por isso, a corrupção das línguas seja identificada por Condillac como sendo uma das causas do declínio de uma nação. ${ }^{11}$

\section{Consideraçóes finais}

Eis o que chamamos inicialmente de "lugar estratégico" da análise condillaciana da origem da poesia. Aparentemente secundárias, as observações do filósofo acerca desse tema póem em relevo dois elementos centrais dos perigos da linguagem estreitamente ligados ao declínio das civilizaçóes. Tais observaçóes, em primeiro lugar, chamam a atenção para um elemento constitutivo da concepção condillaciana de linguagem: a possibilidade do uso trópico ou metafórico dos signos. Em segundo lugar, elas fornecem pistas sobre consequências - tanto positivas quanto negativas - decorrentes desse emprego dos signos.

O primeiro ponto, vale esclarecer, decorre do fato de que, para Condillac, os signos da linguagem de ação (matriz de todas as outras formas linguísticas) são elaborados a partir de reaçôes do corpo (o grito de dor, por exemplo), ligadas a certas sensaçóes com as quais não possuem nenhuma relação essencial. Ora, se é assim, os signos derivados dessa raiz serão igualmente desprovidos desse tipo de relação com os conteúdos que designam (KOSSOVITCH, 2011, p. 60).

Ora, não é difícil constatar as implicaçóes profundamente antimetafísicas dessa genealogia da linguagem, já que, desde o início, ela exclui a hipótese segundo a qual o signo teria, no dizer de Foucault, "identidade de conteúdo" com aquilo que ele significa. ${ }^{12}$ Posto de outra maneira, para o abade, não há relaçôes internas ou essenciais entre os objetos e suas designaçóes na linguagem. E não poderia ser de outro modo, pois, no quadro do empirismo radical de Condillac, no qual é impossível o conhecimento das essências, é a partir da "aparência" dos objetos e de nossa conformaçáo fisiológica que são instituídos seus signos (CONDILLAC, 2016, p. 167). No limite, é porque somos capazes de manipular a voz, por exemplo, que, dadas certas sensaçóes e

\footnotetext{
${ }^{11}$ Como afirma Coski: "O gosto e a estética do gênio literário são inseparáveis de um conceito mais amplo de progresso. Todas as artes, não só as 'belas artes', mas, também, as liberais, as mecânicas, militares e políticas se beneficiam da onda de evolução linguística que é inflamada pelo escritor." (COSKI,2006, p. 166).

12 Como afirma Foucault, em As palavras e as coisas: "O grito não se assemelha ao medo, a mão estendida nấo se assemelha à fome. Tais signos foram, de uma vez por todas, instaurados pela natureza, mas nâo exprimem a natureza daquilo que designam.” (FOUCAULT, 2002, p. 211).
} 
emoções, podemos nomeá-las, não necessitando para isso de conhecer o em si que tais sensaçóes poderiam, porventura, representar. Se quisermos considerar a questão de um ponto de vista alargado, podemos sustentar que o abade se encontra no extremo oposto da tradição inaugurada talvez pelo Crátilo de Platão, como Condillac indica, em sua Gramática.

O que importa é que, se é assim, está aberta a possibilidade da linguagem figurada. Afinal, se a palavra não exprime essência alguma, o sentido primeiro de um vocábulo qualquer sempre poderá ser deslocado para designar novos conteúdos, ou seja, o nome próprio admite um uso figurado que estende sua esfera de significação. Mais que isso, como afirmará mais tarde o autor, levando essa constatação ao extremo, em $A$ arte de escrever: "[...] em sua origem, a linguagem é sempre figurada", e a significação de um nome sempre poderá ser deslocada de sua acepção original para designar um objeto ainda não nomeado ou descrever características de um outro. Em suma, todo nome pode ser convertido em um tropo, termo que, na filosofia condillaciana, diferentemente do que ocorre na retórica, designa de maneira geral os deslocamentos de sentido, como se pode ver, no verbete "Tropo", do Dicionário de sinônimos:

Tropo. s.m. De um termo grego que significa virar (tourner). É o uso que se faz de uma palavra desviando-a de sua significação primitiva. Metáfora, a consultar a etimologia, é a mesma coisa. Mas os retóricos comumente dão esse nome apenas as figuras que são resultados de uma comparação (CONDILLAC, 1951, p. 544).

Observe-se que essa não é necessariamente, por assim dizer, uma má notícia. A importância dos tropos é capital, pois, como nota Leon Kossovitch, com eles, o "campo se amplia":

O termo inicial é o nome próprio: é tomado no sentido primitivo quando significa a ideia para a qual foi estabelecido; mas quando esse termo significa outra ideia, adquire novo sentido, o do empréstimo, passando a chamar-se tropo ou figura (KOSSOVITCH, 2011, p. 60).

O bom uso dos tropos confere plasticidade à linguagem, permitindonos designar coisas para as quais não teríamos nomes, dar corpo àquelas que não caem sob nossos sentidos e atribuir a cada pensamento o caráter que lhe é próprio. Em suma, a possibilidade de deslocar o sentido original de um termo, desde que se tenha como ponto de partida alguma analogia que permite ver qual sua relação com seu sentido original, representa um enriquecimento da 
linguagem. Um exemplo evidente desse aspecto positivo é o da alma e de sua descrição, apresentadas pelo autor, em $A$ arte de escrever:

\begin{abstract}
Nomeamos, por exemplo, alma ou espírito essa substância que é a única que sente, a única que pensa. Tais denominaçóes originariamente significavam apenas um sopro, um ar sutil. Deseja-se falar de suas qualidades? Parecemos comunicar a elas as do corpo, dizemos: "a extensão, a profundidade, os limites do espírito; as tendências, as inclinações os movimentos da alma" (CONDILLAC, 1947, p. 560).
\end{abstract}

A mobilidade do signo é, portanto, fundamental para o próprio desenvolvimento da linguagem. É a partir dela que novas designaçóes podem ser criadas e o sistema linguístico pode alargar-se, estendendo-se para além de seus limites originais. As designações, e com elas o conhecimento, se ampliam, na medida em que tanto ideias de coisas que não se apresentam diretamente aos sentidos (caso da alma) quanto ideias gerais (como a ideia de humanidade) podem ser pensadas graças a esses deslocamentos e associaçôes.

Todavia, como o capítulo sobre a poesia (ao condenar o uso excessivo de figuras e metáforas) já alerta o leitor, se o deslocamento semântico amplia o campo do pensável e do analisável, ele abre, ao mesmo tempo, a possibilidade dos abusos de linguagem. A invenção apropriada de novos signos e o bom uso dos tropos dependem da observância atenta da analogia; relação que deve servir de fio condutor nessa elaboração, evitando que a referência inicial fornecida pelas sensaçôes se perca, perdendo-se com ela a própria inteligibilidade dos sistemas linguísticos. O perigo do abuso é sempre considerável, mas será sempre maior em se tratando das "línguas vulgares", pois, no caso dessas últimas, não é o guia fornecido pela analogia, porém, a contingência histórica que introduz a variação. Formadas no decorrer da história, resultantes de diferentes interaçóes entre as naçóes, elas são, na verdade, como se afirma na Língua dos cálculos, “[...] detritos de línguas que não são mais faladas." (CONDILLAC, 2016, p. 263). Nelas, a analogia entre os signos não é clara e coerente (como na língua "controlada" da matemática), razão pela qual tais línguas terminam por constituir instrumentos precários de análise da experiência e por impor dificuldades ao raciocínio.

Em suma, a mesma propriedade que amplia as possibilidades da linguagem encerra o germe de sua corrupçáo, conforme assinala o autor, numa passagem do Ensaio que sintetiza a trilha seguida no uso progressivo dos tropos: 
E assim as figuras e as metáforas, de início, inventadas pela necessidade, em seguida escolhidas para servir ao mistério, tornaram-se ornamento do discurso, quando poderiam ter sido empregadas com discernimento; e é assim que, na decadência das línguas, elas desferiram os primeiros golpes, graças ao abuso que delas foi feito (CONDILLAC, 2018, p. 267).

O problema é que o abuso da linguagem parece ser inevitável e, com ele, a decadência das línguas. Afinal, desde o início, o uso das palavras é figurado, e o perigo da degeneraçáo dos termos em signos vazios de sentido sempre está à espreita. Mas, além disso, uma vez que a história natural da origem e dos progressos das línguas é concebida segundo o modelo fornecido pela geração animal, tudo deve se passar de modo semelhante ao ocorre, nas palavras do filósofo, no "mundo físico" onde "[...] o mesmo movimento que fora um princípio de vida torna-se um princípio de destruição." (CONDILLAC, 2018, p. 278). Isto é, o mesmo impulso que leva os homens à invenção dos signos e ao cultivo da linguagem tende, ao cabo, a seu esgotamento e à corrupção. Por isso, quando se chega ao ápice de uma língua, seu declínio poderá até ser protelado, mas o desfecho parece ser inevitável. "Quando se chega a esse ponto, pode-se retardar, mas dificilmente evitar a queda de uma língua." (CONDILLAC, 2018, p. 267).

Tal constatação não é de pouca consequência. Se é do desenvolvimento da linguagem, entre outros fatores, que depende o progresso das artes e das ciências, atividades que, para Condillac, definem as naçóes esclarecidas, o declínio de uma língua pode levar à decadência de uma nação. Não por acaso, na introdução ao Curso de História, o filósofo previne o leitor de que o que se verá ali é uma série de revoluçóes. E, via de regra, no decorrer destas, umas poucas naçôes "privilegiadas" emergem de uma "barbárie ignorante", adquirem as ciências e as artes, tornam-se "esclarecidas". Mas, tendo chegado ao seu auge, essas mesmas nações se precipitam no declínio. Inicia-se, entâo, um período dominado por uma barbárie de natureza mais perniciosa, porque refinada e viciosa, devido ao próprio cultivo das artes e das ciências.

No desenvolvimento dessas poucas nações afortunadas, conforme a síntese elegante de Leon Kossovitch (2011, p. 95), [t] rês estágios se destacam: princípio, progresso e decadência, a qual, na forma aguda do declínio, é o estágio final, quando predominam o vício e a corrupção." Pode-se debater se se trata simplesmente de tendência predominante ou se esse é o fim inevitável das naçóes. Como quer que seja, o fato é que esse diagnóstico contrasta, a olhos 
vistos, com a largamente difundida opiniáo que associa as Luzes à crença no progresso contínuo da civilização.

SALLES, F. O. Of the origin of poetry: rise and decline of languages in Condillac. Trans/form/ ação, Marília, v. 44, n. 2, p. 181-198, Abr./Jun, 2021.

\begin{abstract}
In this paper we aim to show de importance of Condillac's reflexions on poetry in the context of his theory of the genesis and progress of language. At first glance, these reflexions seems to be as only a few steps, merely necesserely to complete his history of that process. But, after a close examination, they acquire another sense and importance. As they show that the metaphorical or tropic use of signs is present from the very beggining of verbal communication, they allow us to think about its advantages and dangers. This last aspect has serious consequences for Condillac's conception of the progress of mankind that intend merely to indicate here.
\end{abstract}

Key Words: Poetry. Tropes. Sign. Language of action.

\title{
REFERÊNCIAS
}

AUROUX, S. Condillac ou la vertu des signes. In: AUROUX, S.; CHOUILLET, A.M. (org.). Condillac, la langue des calculs. Lille: Presses Universitaires de Lille, 1981.

CHARRAK, A. Empirisme et metaphysique: L' Essai sur l'origine des connaissances humaines de Condillac. Paris: Vrin, 2003.

CONDILLAC, É. B. L'art d'Écrire. In: LE ROY, G. (org.). Oeuvres philosophiques de Condillac, tomo 1. Paris: PUF, 1947a.

CONDILLAC, É. B. Traité des Systêmes. In: LE ROY, G. (org.). Oeuvres philosophiques de Condillac, tomo I. PUF: Paris, 1947b.

CONDILLAC, É. B. Correspondance. In: LE ROY, G. (Org.). Oeuvres philosophiques de Condillac, tomo 1. Paris: PUF, 1948.

CONDILLAC, É. B. Dictionnaire des sinonymes. In: LE ROY, G. (org.). Oeuvres philosophiques de Condillac, tomo III. Paris: PUF, 1951.

CONDILLAC, É. B. Tratado das sensaçóes. Tradução de Denise Bottmann. Campinas: Editora da UNICAMP, 1993.

CONDILLAC, É. B. A língua dos cálculos. In: SALLES, F. (org.). Lógica e outros escritos. São Paulo: Editora da UNESP, 2016. 
CONDILLAC, É. B. A arte de escrever. In: CONDILLAC, É. B. Ensaio sobre a origem dos conhecimentos humanos. Traduçao de Pedro Paulo Pimenta. São Paulo: Editora UNESP, 2018.

CONDILLAC, É. B. Ensaio sobre a origem dos conhecimentos humanos. Tradução de Pedro Paulo Pimenta. São Paulo: Editora UNESP, 2018.

COSKY, C. Emotion and poetry in Condillac's theory of language and mind. The French Review, v. 80, n. 1, p. 157-170, 2006. Disponível em: https://www.jstor.org/ stable/25480591. Acesso em: 10 out. 2018.

KOSSOVITCH, L. Condillac lúcido e translúcido. São Paulo: Ateliê, 2011.

FOUCAULT, M. As palavras e as coisas. São Paulo: Martins Fontes, 2002.

LIFSCHITZ, A. The Arbitrariness of the Linguistic Sign: Variations on an Enlightenment Theme. Journal of the history of ideias, v. 73, n. 4, p. 537-557, 2012. Disponível em: https:/www.jstor.org/stable/23353978. Acesso em: 22 out. 2018.

RIEU, A. M. Complexe nature-science-langage chez Condillac. In: SGARD, J. (org.). Condillac et les problèmes du langage.Genebra - Paris: Slaktine, 1982.

Recebido: 29/11/2018

Aceito: $22 / 2 / 2020$ 
SALLES, F. O. 